\title{
Surveillance of Mosquitoes (Diptera, Culicidae) in a Northern Central Region of Spain: Implications for the Medical Community
}

\section{OPEN ACCESS}

Edited by:

Michael Kosoy,

Centers for Disease Control and Prevention (CDC), United States

Reviewed by:

Rubén Bueno-Marí, Lokimica Laboratorios, Spain Hans-Peter Fuehrer,

Vetmeduni Vienna, Austria Cristina Pou-Barreto,

Universidad de La Laguna, Spain

*Correspondence: José Antonio Oteo jaoteo@riojasalud.es

Specialty section: This article was submitted to Parasitology,

a section of the journal Frontiers in Veterinary Science

Received: 23 November 2018 Accepted: 05 March 2019 Published: 23 April 2019

Citation:

Ruiz-Arrondo I, McMahon BJ, Hernández-Triana LM, Santibañez $P$,

Portillo A and Oteo JA (2019) Surveillance of Mosquitoes (Diptera,

Culicidae) in a Northern Central Region of Spain: Implications for the

Medical Community.

Front. Vet. Sci. 6:86.

doi: 10.3389/fvets.2019.00086

\author{
Ignacio Ruiz-Arrondo ${ }^{1}$, Barry J. McMahon ${ }^{2}$, Luis M. Hernández-Triana ${ }^{3}$, \\ Paula Santibañez ${ }^{1}$, Aránzazu Portillo ${ }^{1}$ and José Antonio Oteo ${ }^{1 *}$ \\ ${ }^{1}$ Center of Rickettsiosis and Arthropod-Borne Diseases, Hospital Universitario San Pedro-CIBIR, Logroño, Spain, ${ }^{2}$ UCD \\ School of Agriculture and Food Science, University College Dublin, Dublin, Ireland, ${ }^{3}$ Wildlife Zoonoses and Vector-Borne \\ Diseases Research Group, Virology Department, Animal and Plant Health Agency, Addlestone, United Kingdom
}

Mosquitoes are important to public and animal health due to their capacity to transmit diseases. Since the Zika virus was declared a pandemic by the WHO in 2016, and it has been recorded in different regions of Mediterranean Area (included Spain), the Government of La Rioja (Northern Spain) through the Center of Rickettsiosis and Arthropod-Borne Diseases, implemented an entomological surveillance programme of mosquitoes in La Rioja and in a close area of Navarra. This surveillance extended to some of the pathogens that they can transmit. Here we describe the framework of the initial surveillance programme for the detection of mosquitoes and associated human pathogens. We outline the benefits and the limitation of the programme to date, and explore how greater benefits can be achieved, for example using a One Health approach. Entomological surveillance has been carried out with BG-Sentinel traps, human bait technique and other methods such as collecting adults in resting places or immature stages by dipping in several wetlands. Since Aedes albopictus, vector of arbovirus such as Dengue, Chikungunya, and Zika, has not been detected yet in the region, the entomological programme included the surveillance of this exotic species using ovitraps in the most important cities. Morphological identification was supported using the mitochondrial cytochrome $\mathrm{C}$ oxidase subunit I and the internal transcribed spacer 2 genes analysis. In 2016 and 2017, more than 6,000 mosquitoes were collected. The mosquito's community included 21 species associated with six genera: Anopheles $(n=4)$, Aedes $(n=5)$, Culex $(n=6)$, Culiseta $(n=4)$, Uranotaenia $(n=1)$ and Coquillettidia $(n=1)$. Eleven species represent new records for La Rioja and Navarra regions. Several species were collected biting humans and a great proportion of the sampled mosquito population are competent vectors of several pathogens, such as West Nile virus. Sequences closely related to mosquito-only flavivirus have been detected in $0.34 \%$ of analysed pools. At the same time, the epidemiological surveillance emphasis is placed in the early detection of mosquito-borne diseases in primary health and emergency services. The surveillance programme represents a relevant and necessary assessment of the risk of pathogen transmission in a region, and it allows for the establishment of the appropriate preventive measures.

Keywords: surveillance, mosquito, One Health, flavivirus, molecular identification, La Rioja, Northern Spain 


\section{INTRODUCTION}

Mosquitoes are considered the most important arthropod vectors in the world $(1,2)$. Globalization in conjunction with climate change, landscape change and the capacity of mosquitoes to adapt to a changing world favour the emergence and re-emergence of numerous mosquito-borne diseases $(3,4)$.

Vector-borne diseases are increasing in Europe with the presence of alien and native species of mosquitoes. Thus, the invasive tiger mosquito (Aedes albopictus) has been involved in the transmission of Chinkungunya virus (CHIKV), and autochthonous cases of CHIKV have been reported in France and Italy from 2007 to 2017 (5, 6). Aedes albopictus has been also related to cases of Dengue virus (DENV) reported in France from 2010 to 2015 (7). More recently, DENV has been recorded from Spain, and again in France $(8,9)$. Moreover, native species such as Culexpipiens s.l. or Anopheles atroparvus, could play a prominent role in the transmission of pathogens, such as the West Nile virus (WNV) (10) or malaria, respectively $(11,12)$.

The emergence and resurgence of some mosquito-borne diseases has led to the implementation of mosquitoes and arboviruses surveillance programs in some European countries, in an effort to reduce the impact of these infections on public health (13). Arboviruses surveillance requires a One Health approach that integrates the health of humans, animals (livestock and wildlife), and the ecosystems to prevent disease outbreaks (14). This includes the surveillance of mosquitoes. Research on the distribution, abundance and species composition of mosquitoes in a region is vital in order to estimate the risk of incidence of vector-borne diseases (15-17).

Mosquito-borne disease surveillance programs vary among European countries, according to different environmental and socio-economic scenarios (18) and, to a greater or lesser extent, within the One Health perspective. This is, for instance, the case of West Nile disease (WND) surveillance program. WNV remains in an enzootic cycle among birds, and it does not easily adapt to urban spaces (19). Mosquitoes of the genus Culex are the main vectors in Europe (18), and humans and equids are accidental hosts. WNV is continuously circulating in Europe with a recent increasing trend of incidence in several European countries (20). In Spain, a country where WNV is endemic (21), a specific national surveillance plan for WNV has been carried out since 2007 in high risk areas, located mainly in southern Spain. Nevertheless, WNV screening in mosquitoes had been previously done in wetlands in western Andalucía (2001-2013) and Catalonia (2001-2009) (18). In addition to the entomological surveillance, both passive and active surveillance were carried out on birds and horses (22).

In February 2016, WHO declared Zika virus (ZIKV) infection as a public health emergency of international importance due to its rapid expansion over-wide and severe complications, including congenital microcephaly and Guillain-Barré syndrome (23). In Spain, a National Plan of preparedness and response against CHIKV, DENV, and ZIKV was then developed (23) due

Abbreviations: CHIKV, Chinkungunya virus; DENV, Dengue virus; USUV, Usutu virus; WNV, West Nile virus; ZIKV, Zika virus. to the presence of Ae. albopictus in several regions of the country (24). At the same time, the 17 Autonomous Communities from Spain were urged to make their own plans against this mosquito threat. The latter and the lack of knowledge about the circulation of mosquitoes in La Rioja (northern central of Spain), urged La Rioja Government to implement a mosquito (and their related microorganisms) surveillance program in the region in 2016, through the Center of Rickettsiosis and Arthropod-Borne Diseases (CRETAV).

CRETAV is a reference centre for arthropod-borne diseases in Spain. A multidisciplinary team (physicians, biologists, veterinarians, entomologists, biochemists and pharmacists) works in coordination dedicated to the study of these zoonosis, focused on the One Health concept. In addition, physicians who treat patients with febrile syndromes are sensitized with the emergence and re-emergence of diseases transmitted by arthropod vectors (25-27).

Within the regional plan for surveillance of arboviruses in La Rioja, a coordinated group among the different sectors involved was formed to follow up on imported cases and adequately respond to risk situations. The key elements within this plan were: epidemiological, entomological and microbiological surveillance, entomological response, individual protection, training and information, and coordination and communication (28); thus requiring a multidisciplinary team which needs to understand the ecology of the mosquitoes. Specifically, the main measures were focused on entomological surveillance as well as epidemiological surveillance of imported cases in case of Ae. albopictus (and/or other competent vector) detection. The aim of this manuscript was to describe initial surveillance programme for the detection of mosquitoes and associated human pathogens. The study involved not only mapping the mosquito species distribution, but also investigating their abundance, phenology and preference for hosts. It was focused on the collection of ecological data to inform about the epidemiology of mosquito-borne diseases. We outline the benefits and the limitation of the programme to date, and explore how greater benefits can be achieved, for example using a One Health approach.

\section{METHODOLOGY}

\section{Study Area}

The study area is located in the Autonomous Community of La Rioja (northern Spain) and a close area of Navarra region (Figure 1). La Rioja is a small region $\left(5,034 \mathrm{~km}^{2}\right.$ and 312,830 inhabitants) in Spain. It has different habitats with great biodiversity. Its territory expands between the plain in the North, with the Ebro river Valley, with altitudes between 300 and 400 metres above sea level (m.a.s.l.), and the mountains in the South, with the presence of several valleys with North-South direction, with maximum altitude of 2,271 m.a.s.l. (29). The climate is temperate with variations according to altitude.

The entomological surveillance encompasses areas placed in Iregua river (in Logroño) as well as La Grajera and Las Cañas wetlands (the last one in Navarra region), both located very close to Logroño (red points, Figure 1). These areas were 


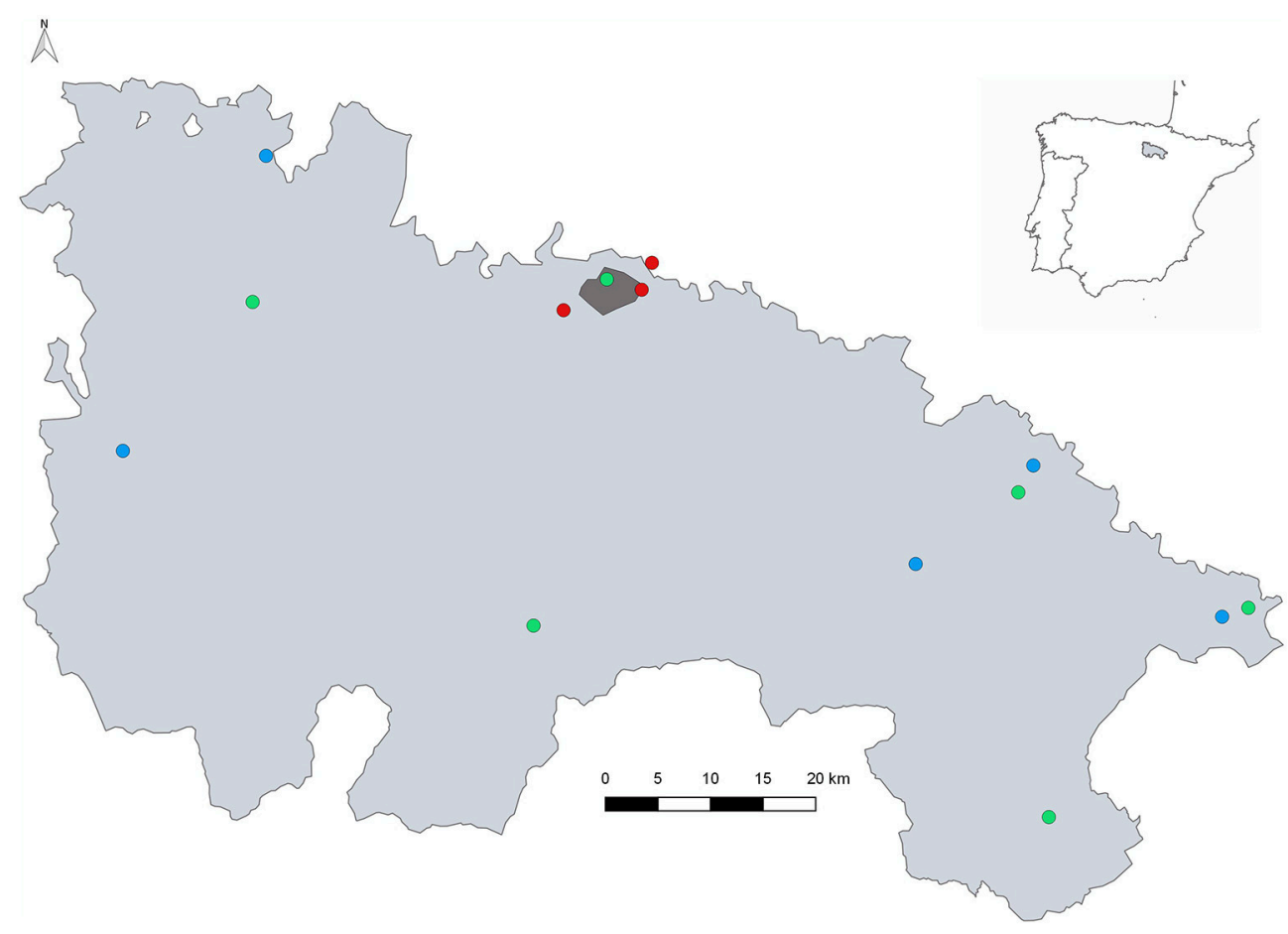

FIGURE 1 | Distribution of the mosquito sampling sites. Dark grey is the urban zone of Logroño city; red circles indicate wetlands and river Iregua sampled permanently; green points are wetlands visited occasionally; and blue circles indicate the municipalities with presence of ovitraps. The map was created using QGIS 2.8 .

chosen according to the presence of mosquitoes, waterfowl and migratory bird species, and because they were regularly visited by the public. This situation makes these wetlands points of specific interest for monitoring arboviruses. The entomological surveillance also included sporadic visits to other wetlands (green points, Figure 1) in order to investigate the mosquito fauna through the entire region of La Rioja. The surveillance of alien species was carried out in six municipalities (blue points and Logroño city, Figure 1). Geolocation of sampling sites are included in Table S1.

\section{Mosquito Collection}

Entomological surveillance was carried out using different collecting techniques: Trapping devices, human landing technique and other methods, such as collecting adults in resting places or catching immature stages by dipping.

Mosquitoes were collected from July to September 2016, and from May to September 2017. A total of 16 BG-1 Sentinel ${ }^{\mathrm{TM}}$ traps (BioGents GmbH, Regensburg, Germany) baited with BG-Lure ${ }^{\circledR}$ and $\mathrm{CO}_{2}$ were set once every 2 weeks in wetlands.

Traps were placed at dusk and checked the following morning and, at the same time, the mosquitoes were captured by human landing technique during 10 min per trap using mouth aspirators (30). Resting adults were captured from natural and artificial hiding places and the surrounding vegetation in breeding sites by vacuuming (31) using an InsectaZooka and an AC/DC aspirators (Bioquip Products, Rancho Dominguez, CA, USA).

The entomological programme also included the surveillance of Ae. albopictus using ovitraps (31) in the most important cities because it was known to be present in three border regions, the Basque country, Aragón (32), and in Navarra (unpublished data). A total of 80 ovitraps locations were chosen in selected municipalities (blue points and Logroño city, Figure 1). The ovitraps were checked every 2 weeks for Ae. albopictus eggs from July to October 2016-2017.

\section{Mosquito Identification and Viruses Screening}

Collected adult specimens were placed into a cooler containing dry ice and transported to the laboratory for storage at $-80^{\circ} \mathrm{C}$ until processing. Larval specimens were preserved in $80 \%$ ethanol until mounted on slides and pupae were conserved with water from breeding place to obtain linkreared adults. Adults were separated on a chill table, according to their gender and their engorged status. Wooden sticks of the ovitraps were checked under a stereoscope in the search of eggs. If present, they were introduced into water for hatching, following the protocol of Alarcón-Elbal et al. (33). All specimens were morphologically classified using taxonomic keys $(34,35)$.

Molecular identification was carried out in selected adults and in unhatched eggs using PCR assays targeting the mitochondrial cytochrome $\mathrm{C}$ oxidase subunit I (COI) and the internal transcribed spacer 2 (ITS2) (36). A modified hotshot technique was used for DNA extraction using only leg(s) from the adult specimen (37). Eggs collected on every wooden stick were pooled, and DNA was extracted using 
the kit DNeasy Blood and Tissue (Qiagen, Hilden, Germany). PCR products were sequenced in both senses using the BigDye ${ }^{\circledR}$ Terminator v3.1 Cycle Sequencing Kit (Applied Biosystems, Forest City, CA, USA) at the Sequencing Unit, Center for Biomedical Research of La Rioja (CIBIR), Spain. Nucleotide sequences were compared with those deposited in GenBank using BLAST tool (www.ncbi.nlm.nih.gov/genbank), and in BOLD Systems (http://www.boldsystems.org/index.php/ IDS_IdentificationRequest). Neighbour joining analyses were conducted in MEGA4. Detailed specimen records and sequence information (including trace files) are available on Barcode of Life Database (BOLD) (see http://www.boldsystems.org) and Genbank.

After identification, unfed female mosquitoes were pooled (a maximum of 50 individuals/pool) by wetland, collection date and species. The RNA was extracted from the homogenates and reverse-transcribed using RNeasy Mini Kit and Omniscript RT kit (Qiagen, Hilden, Germany), respectively, following the manufacturer's instructions and tested for flavivirus using a generic nested PCR assay (38). Japanese Encephalitis virus was used as positive control. The strains-14 was obtained through the European Virus Archive (EVAg) consortium and passed three times in Vero Cells. All procedures were carried out under sterile conditions in a Class II biosafety cabinet in a biosafety level 2 laboratory at CIBIR. PCR products were sequenced and analyzed as explained above.

\section{RESULTS}

\section{Identification of Mosquitoes}

In the studied period 2016-2017, a total of 6,658 mosquitoes were collected by traps in permanently sampled wetlands. The community composition of the samples included 21 species belonging to six genera: Anopheles $(n=4)$, Aedes $(n=5)$, Culex $(n=6)$, Culiseta $(n=4)$, Uranotaenia $(n=1)$ and Coquillettidia $(n=1)$ (Table 1). Eleven species represented new records for La Rioja (Anopheles algeriensis, Anopheles plumbeus, Aedes berlandi, Aedes cantans, Aedes vexans, Aedes detritus, Coquillettidia richiardii, Culex theileri, Culiseta litorea, Culiseta subochrea, and Uranotaenia unguiculata) added to the fourteen species previously described in the region $(43,44)$. Five species were new records for Navarra (region nearby of La Rioja) (An. algeriensis, An. plumbeus, Ae. detritus, Cs. litorea and Cs. subochrea) along with the fourteen species previously reported $(45,46)$. During the surveillance in 2016, eggs that morphologically seemed compatible with those from $A e$. albopictus were detected, although the identification could not be confirmed by molecular methods. To date, Ae. albopictus has not been detected in La Rioja or in the studied area of Navarra.

Table 1 shows the capture methods for each species with six species that were collected biting humans: An. plumbeus, Ae. cantans, Aedes caspius, Ae. detritus, Ae. vexans, and Cq. richiardii. All identified species have been molecularly confirmed.

TABLE 1 | Mosquito species captured with different collection methods and vector competence for humans (34, 35, 39-42).

\begin{tabular}{|c|c|c|c|c|c|}
\hline \multirow[t]{2}{*}{ Species } & \multicolumn{4}{|c|}{ Collection method } & \multirow{2}{*}{$\begin{array}{l}\text { Vector competence } \\
\text { (confirmed in laboratory) }\end{array}$} \\
\hline & $\mathbf{T}$ & HB & $\mathbf{R}$ & D & \\
\hline Anopheles algeriensis Theobald, 1903 & $x$ & & $x$ & & Plasmodium sp. \\
\hline Anopheles atroparvus Van Thiel, 1927 & $x$ & & $x$ & $x$ & Plasmodium sp. WNV \\
\hline Anopheles claviger s.I. (Meigen, 1804) & $x$ & & $x$ & & Plasmodium sp. \\
\hline Anopheles plumbeus Stephens, 1828 & $x$ & $x$ & & & Plasmodium sp. WNV \\
\hline Aedes berlandi Seguy, 1921 & $x$ & & & & - \\
\hline Aedes cantans (Meigen, 1818) & & $x$ & & & Tahyna virus WNV \\
\hline Aedes caspius (Pallas, 1771) & $x$ & $x$ & $x$ & & Tahyna virus WNV \\
\hline Aedes detritus (Haliday, 1833) & $x$ & $x$ & & & JE virus WNV \\
\hline Aedes vexans (Meigen, 1830) & $x$ & $x$ & & & EEE virus RVF virus Tahyna virus WNV \\
\hline Culex hortensis Ficalbi, 1889 & $x$ & & & $x$ & - \\
\hline Culex impudicus Ficalbi, 1890 & $x$ & & $x$ & $x$ & - \\
\hline Culex mimeticus Noè, 1899 & $x$ & & & & WNV \\
\hline Culex modestus Ficalbi, 1889 & $x$ & & & $x$ & Lednice virus Tahyna virus WNV \\
\hline Culex pipiens s.I. Linnaeus, 1758 & $x$ & & $x$ & $x$ & Sindbis virus Usutu virus JE virus SLE virus RVF virus WNV \\
\hline Culex theileri Theobald, 1903 & $x$ & & $x$ & $x$ & Sindbis virus RVF virus WNV \\
\hline Culiseta annulata (Schrank, 1776) & $x$ & & $x$ & $x$ & WNV \\
\hline Culiseta longiareolata (Macquart, 1838) & $x$ & & $x$ & $x$ & - \\
\hline Culiseta litorea (Theobald, 1901) & $x$ & & & $x$ & - \\
\hline Culiseta subochrea (Edwards, 1921) & $x$ & & $x$ & $x$ & - \\
\hline Coquillettidia richiardii (Ficalbi, 1889) & $x$ & $x$ & $x$ & & WNV \\
\hline Uranotaenia unguiculata Edwards, 1913 & $x$ & & $x$ & $x$ & - \\
\hline
\end{tabular}

T, BG-1 Sentinel ${ }^{T M}$ trap; HB, Human-bait; R, Rest; D, Dipping; EEE, Easter equine encephalitis; JE, Japanese encephalitis; SLE, Sant Louis encephalitis; RVF, Rift Valley fever. 
In total, we obtained 262 full length 658 bp barcodes for COI and 47 barcodes for ITS2. The neighbour joining (NJ) trees show that all specimens belonging to the same species based upon morphological characters grouped together in the tree (Figure 2). Anopheles claviger s.l. was not included in the ITS2 NJ tree because of failure of DNA amplification. In addition, for those samples that showed PCR products, the obtained sequences were too short to be included in the dataset.

Regarding blood-fed, 341 female specimens were collected. Forty per cent of the samples were caught in the BG-1 Sentinel ${ }^{\mathrm{TM}}$ traps, and the remaining $60 \%$ in resting places.

The composition and the abundance of the species varied depending on the wetland (see Table 2). In La Grajera wetland, Cq. richiardii (43.7\%), Cx. pipiens s.l. (16.9\%), An. algeriensis (15.9\%) and An. claviger s.l. (11.5\%) were the most abundant species, whereas in Las Cañas wetland, Ae. caspius (47\%) and $C x$. pipiens s.l. (23\%) were the main collected species. In Iregua river, Cx. pipiens s.l. (64.4\%) and Cx. modestus (12.5\%) were the most common species. In occasionally sampled wetlands, all but Aedes cantans species were the same as those found in permanently

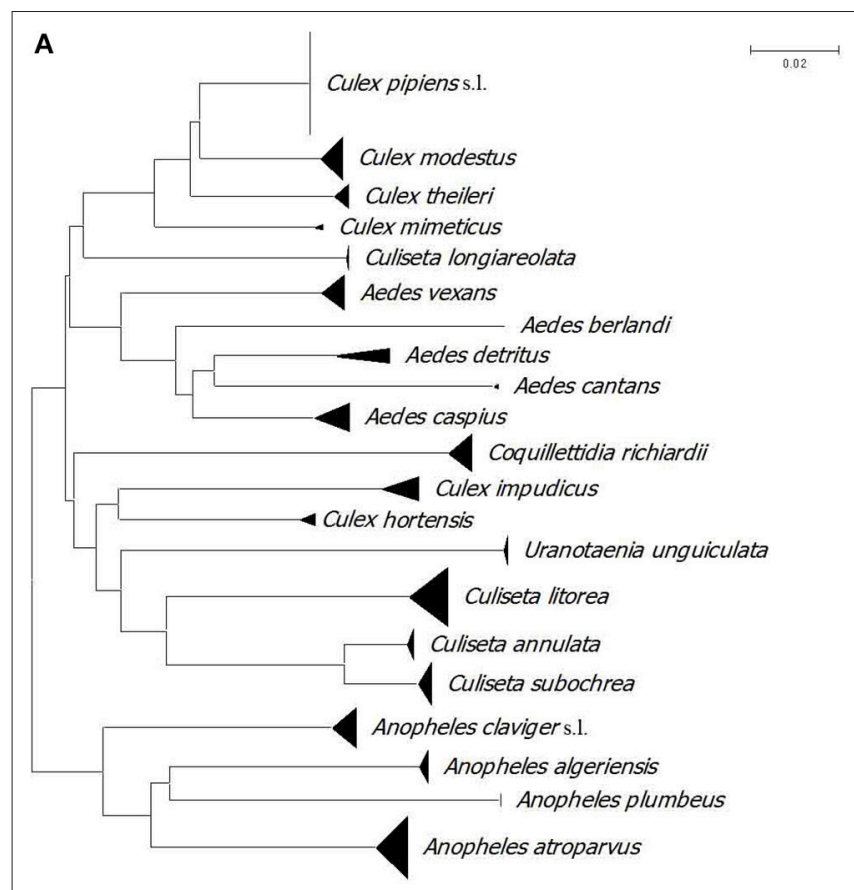

B

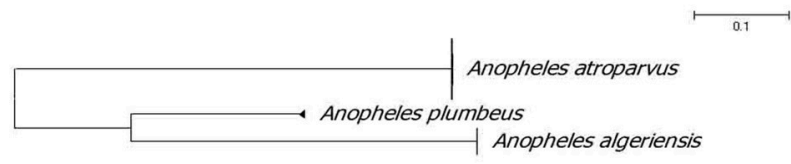

FIGURE 2 | (A) Neighbour joining tree of COI DNA barcodes (658 bp) for mosquito species collected in La Rioja, Spain. (B) Neighbour joining tree of ITS2 sequences (475 bp) for Anopheles species collected in La Rioja, Spain. A divergence of $>2 \%$ might be indicative of separate operational taxonomic units. sampled sites. Phenology and ecological data have been obtained and those from 2017 in La Grajera wetland have been already published (30).

\section{Screening for Flaviviruses}

Up to date, four pools (0.34\%), three from La Grajera wetland and one from Las Cañas wetland, from Ae. vexans captured in 2016 and 2017, have yielded positive results for flavivirus PCR screening (Table 3). They showed maximum identity (9799\%) with the sequences of Aedes vexans flavivirus (AeveFV) group deposited in GenBank (GQ476996- GQ476998, GQ477000 and JN802280).

\section{DISCUSSION}

This is the first study performed in northern central Spain focused on the investigation of the mosquito species and their potential infections with flaviviruses. In Spain, mosquito screening for arboviruses had been previously performed in other regions, like Catalonia and Western Andalusia (47-49). The study has allowed us to identify numerous mosquito species with vector capacity as well as providing an insight into the ecology of these vectors. Sequences closely related to mosquitoonly flavivirus have been detected in the analysed samples. The surveillance of mosquito's circulation is very important for the clinical practice since travellers affected by DENV, CHIKV and ZIKV have been diagnosed in the country, and because the first autochthonous cases of Dengue have been reported in Spain as well as in neighbouring countries (8).

Since Ae. albopictus has not been detected in the region, the risk of autochtonous transmission of arbovirus like DENV, CHIKV, and ZIKV remains very low. This fact means that the next level of action within the regional plan for surveillance of arboviruses in La Rioja should not be extended and, among other measures, epidemiological surveillance and control of the vector have not been necessary in the case of imported cases of arboviruses.

In this study, six mosquito species were found biting humans. Some species, like Ae. caspius or Cq. richiardii, are very abundant in the studied area and could act as bridge vectors for pathogens such as WNV, a virus that is endemic in Europe (41). Anopheles plumbeus is the only human-biting anopheline species out of four anopheline species identified herein. This finding suggests that despite its scarcity in the studied area, this species could be the responsible one for the case of autochthonous malaria by Plasmodium vivax that occurred in 2014 in Viana (Navarra), just a few kilometres away from Logroño (50). Anopheles plumbeus is considered a secondary vector of malaria in Europe, but it was implicated as potentially responsible for the transmission of Plasmodium falciparum in Germany (51). Nevertheless, An. atroparvus should not be ruled out as the causative agent. This species, which is more frequent in our area (Table 2), is the recognized main vector of malaria in Europe and it was involved in the transmission of the autochthonous malaria case occurred in Spain in 2010 (11). In addition, An. atroparvus has a wider distribution and activity range in La Rioja since their breeding sites are not restricted to water-filled holes of trees, and it can 
TABLE 2 | Number of mosquitoes (per species and sex), percentage of relative abundance and distribution in the permanently sampled wetlands during $2016-2017$.

\begin{tabular}{|c|c|c|c|c|c|c|c|c|c|c|}
\hline \multirow{2}{*}{$\begin{array}{l}\text { Species } \\
\text { An. algeriensis }\end{array}$} & \multirow{2}{*}{$\begin{array}{c}n \\
617\end{array}$} & \multirow{2}{*}{$\begin{array}{c}\% \\
9.3 \%\end{array}$} & \multirow{2}{*}{$\begin{array}{c}\mathbf{F} \\
613\end{array}$} & \multirow{2}{*}{$\begin{array}{c}\text { M } \\
4\end{array}$} & \multicolumn{2}{|c|}{ Iregua } & \multicolumn{2}{|c|}{ La Grajera } & \multicolumn{2}{|c|}{ Las Cañas } \\
\hline & & & & & 0 & $0.0 \%$ & 587 & $15.9 \%$ & 30 & $1.2 \%$ \\
\hline An. claviger s.l. & 441 & $6.6 \%$ & 440 & 1 & 9 & $2.1 \%$ & 427 & $11.5 \%$ & 5 & $0.2 \%$ \\
\hline An. maculipennis s.I. & 36 & $0.5 \%$ & 19 & 17 & 2 & $0.5 \%$ & 6 & $0.2 \%$ & 28 & $1.1 \%$ \\
\hline An. plumbeus & 5 & $0.1 \%$ & 4 & 1 & 4 & $0.9 \%$ & 0 & $0.0 \%$ & 1 & $0.0 \%$ \\
\hline An. spp. & 33 & $0.5 \%$ & 33 & - & 0 & $0.0 \%$ & 32 & $0.9 \%$ & 1 & $0.0 \%$ \\
\hline Ae. berlandi & 1 & $0.0 \%$ & 1 & 0 & 0 & $0.0 \%$ & 1 & $0.0 \%$ & 0 & $0.0 \%$ \\
\hline Ae. caspius & 1,245 & $18.7 \%$ & 1,245 & 0 & 6 & $1.4 \%$ & 53 & $1.4 \%$ & 1,186 & $47.0 \%$ \\
\hline Ae. detritus & 10 & $0.2 \%$ & 10 & 0 & 0 & $0.0 \%$ & 2 & $0.1 \%$ & 8 & $0.3 \%$ \\
\hline Ae. vexans & 64 & $1.0 \%$ & 44 & 20 & 0 & $0.0 \%$ & 60 & $1.6 \%$ & 4 & $0.2 \%$ \\
\hline Ae. spp. & 40 & $0.6 \%$ & 40 & - & 0 & $0.0 \%$ & 0 & $0.0 \%$ & 40 & $1.6 \%$ \\
\hline Cq. richiardii & 1,857 & $27.9 \%$ & 1,814 & 43 & 8 & $1.9 \%$ & 1,616 & $43.7 \%$ & 233 & $9.2 \%$ \\
\hline Cx. pipiens s.I. & 1,504 & $22.6 \%$ & 1,350 & 154 & 299 & $69.4 \%$ & 625 & $16.9 \%$ & 580 & $23.0 \%$ \\
\hline Cx. modestus & 348 & $5.2 \%$ & 348 & 0 & 54 & $12.5 \%$ & 77 & $2.1 \%$ & 217 & $8.6 \%$ \\
\hline Cx. mimeticus & 4 & $0.1 \%$ & 1 & 3 & 3 & $0.7 \%$ & 1 & $0.0 \%$ & 0 & $0.0 \%$ \\
\hline Cx. theileri & 160 & $2.4 \%$ & 158 & 2 & 2 & $0.5 \%$ & 77 & $2.1 \%$ & 81 & $3.2 \%$ \\
\hline Cx. impudicus & 4 & $0.0 \%$ & 4 & 0 & 0 & $0.0 \%$ & 4 & $0.2 \%$ & 0 & $0.0 \%$ \\
\hline Cx. spp. & 96 & $1.4 \%$ & 96 & - & 21 & $4.9 \%$ & 33 & $0.9 \%$ & 42 & $1.7 \%$ \\
\hline Cs. annulata & 40 & $0.6 \%$ & 40 & 0 & 5 & $1.2 \%$ & 27 & $0.7 \%$ & 8 & $0.3 \%$ \\
\hline Cs. Iongiareolata & 29 & $0.4 \%$ & 22 & 7 & 11 & $2.6 \%$ & 18 & $0.5 \%$ & 0 & $0.0 \%$ \\
\hline Cs. litorea & 30 & $0.5 \%$ & 27 & 3 & 4 & $0.9 \%$ & 17 & $0.5 \%$ & 9 & $0.3 \%$ \\
\hline Cs. subochrea & 88 & $1.3 \%$ & 88 & 0 & 3 & $0.7 \%$ & 37 & $1.0 \%$ & 48 & $1.9 \%$ \\
\hline Cs. spp. & 1 & $0.0 \%$ & 1 & - & 0 & $0.0 \%$ & 1 & $0.0 \%$ & 0 & $0.0 \%$ \\
\hline Ur. unguiculata & 5 & $0.1 \%$ & 4 & 1 & 0 & $0.0 \%$ & 1 & $0.0 \%$ & 4 & $0.2 \%$ \\
\hline Total & 6,658 & & 6,369 & 256 & & & & & & \\
\hline
\end{tabular}

Aedes cantans and Cx. hortensis are not included in the table because they were identified during occasional samplings in 2018. F, Female; M, Male.

breed in a large collection of water bodies such as lagoons, irrigation channels, etc. Several studies have demonstrated that $P$. vivax is well-adapted to European populations of both Anopheles species (52-54). The establishment of the mosquito surveillance programme in La Rioja has contributed to increase the knowledge about the diversity, distribution abundance and ecology of species that are present in the region. These factors may determine the incidence of vector-borne pathogens in vertebrate hosts (55). In the "Big-Data era," the generation of data about the geographic distribution will be useful to recognize possible hotspots for an outbreak and then to start the implementation of preventive measures.

In order to expand the diversity of identified species, different methodologies for mosquito collection were used. Adult trapping is most commonly used to capture flying mosquitoes (31). There are species (e.g. An. atroparvus, Cx. impudicus, and Ur. unguiculata) that have barely been detected using the BG-1 Sentinel ${ }^{\mathrm{TM}}$ traps. This could explain their scarcity in the area. However, the capture of resting mosquitoes has shown that these species mentioned above are more abundant in the sampled wetlands than previously thought. In addition, this technique made possible the capture of numerous engorged females (31).

The molecular identification of mosquitoes proved to be a useful tool to support the morphological identification. Correct identification of mosquito vectors is critical to define pathogen transmission pathways and it is the first step for preventing arboviruses transmission. The use of two genetic markers increased our taxonomic resolution (36). This molecular approach, not only helped us to identify damaged specimens and to distinguish species within a complex, but also allowed us to detect taxonomic errors based on morphological identification alone (36). Nevertheless, we could not obtain the complete fragment ITS2 gene (species-specific for Anopheles) studied for An. claviger sibling species. Kampen et al. (56) previously described also lower ITS2 region lengths for the An. claviger s.l. members than for other species of Anopheles. Both species of the complex, Anopheles claviger s.s. and Anopheles petragnani had been previously reported for several breeding sites in La Rioja region; although their morphological identification was based on preimaginal stages (44). In our study, adult specimens from these two sibling species were morphologically indistinguishable. A deeper study on the molecular identification of this anopheline mosquito complex is required. Molecular identification of all the captured individuals is unsustainable from a cost-effective point of view. However, this tool is highly recommended in groups of species very similar each other that are difficult to identify by classical morphologic and morphometric parameters, such as $C x$. impudicus-Cx. hortensisCx. territans, and Cs. litorea-Cs. morsitans-Cs. fumipennis in our case. This approach has also been developed in other vector surveillance programs in a number of European countries [e.g., $(16,57,58)]$.

The screening for flaviviruses allowed the detection of four genomic sequences closely related to mosquito-only flavivirus group. The sequences showed the highest similarity to flavivirus amplicons of AeveFV group detected in Ae. vexans in Italy 
TABLE 3 | Pools of unfed female specimens from each mosquito species tested up to the moment for this project.

\begin{tabular}{|c|c|c|c|}
\hline Mosquito species & $\begin{array}{l}\text { Number of } \\
\text { tested } \\
\text { mosquitoes }\end{array}$ & $\begin{array}{l}\text { Number of } \\
\text { tested pools }\end{array}$ & $\begin{array}{l}\text { PCR results for } \\
\text { flavivirus } \\
\text { screening }\end{array}$ \\
\hline Anopheles algeriensis & 307 & 15 & - \\
\hline Anopheles claviger s.l. & 36 & 3 & - \\
\hline Anopheles maculipennis s.l. & 14 & 3 & - \\
\hline Anopheles plumbeus & - & - & \\
\hline Aedes berlandi & - & - & \\
\hline Aedes cantans & 1 & 1 & - \\
\hline Aedes caspius & 135 & 9 & - \\
\hline Aedes detritus & 3 & 1 & - \\
\hline Aedes vexans & 18 & 4 & 4 \\
\hline Culex hortensis & - & - & \\
\hline Culex impudicus & - & - & \\
\hline Culex mimeticus & 1 & 1 & - \\
\hline Culex modestus & 106 & 8 & - \\
\hline Culex pipiens s.I. & 573 & 24 & - \\
\hline Culex theileri & 94 & 9 & - \\
\hline Culex spp. & 11 & 2 & - \\
\hline Culiseta annulata & 3 & 1 & - \\
\hline Culiseta longiareolata & 9 & 2 & - \\
\hline Culiseta litorea & 6 & 5 & - \\
\hline Culiseta subochrea & 26 & 7 & - \\
\hline Coquillettidia richiardii & 523 & 21 & - \\
\hline Uranotaenia unguiculata & - & - & \\
\hline Total & 1,866 & 116 & 4 \\
\hline
\end{tabular}

and Czech Republic (59, 60). This is the first report of this AeveFV group in mosquitoes in Spain, although it has been detected previously by another group (Ana Vázquez, personal communication). However, the length of the obtained amplicons did not allow complete phylogenetic characterization. All Ae. vexans pools tested from 2016 to 2017 were positive for RNA flavivirus detection, suggesting active circulation of this flavivirus in this species. Other mosquito-only flaviviruses had been previously detected in Spain in several mosquito species including Ae. vexans $(47,61,62)$. Further analyses of these results are necessary to characterize this flavivirus. The low number of specimens screened for flaviviruses (screening is on-going) does not allow to obtain further conclusions, specially taking into account the low prevalence of pathogenic WNV and Usutu virus (USUV) found in Cx. perexiguus (1.5\%) and Cx. pipiens s.l. $(0.05 \%)$ in Spain (18).

The number of mosquitoes captured in this project is lower compared to other regions from Spain where mosquitoes have been monitored (18). To date, no cases of WNV and USUV have been reported in humans, equids or in birds in northern central Spain, suggesting that there is no circulation of these viruses or, at least, their prevalence is low. In addition, this study adds new species for flaviviruses screening in Spain (e.g., Ae. cantans, Cs. litorea, and Cx. mimeticus) and significantly increases the number of specimens of certain species such as An. claviger s.l. and $C q$. richiardii.

A surveillance of emerging vector-borne infections integrating the animal-human-vector approach is costly to maintain on a long-term basis $(49,63,64)$. Therefore, surveillance have to adapt to the existing reality and cost-effective use of resources at the national and regional levels $(14,18,65)$. The entomological surveillance started in La Rioja represents a good approach to the diagnosis of the situation of possible arboviruses in the region and may provide insights into the change in the force of infection (66) before there is an ecological alteration that may impact on human or animal health. To implement a One Health approach, it would be interesting to complete this surveillance with the screening for flaviviruses in wild birds or other potential sentinel animal species, from wetlands of interest and to include serological testing of sentinel horses. The coordinating efforts from biologists and veterinarians $(18,65,67)$ would be an added value to the ongoing efforts to be aware of medical records and reports of imported mosquito-borne arbovirus human cases in this area. This approach would enable the ecological data to be operationalised to inform human, animal and ecosystem health.

\section{DATA AVAILABILITY}

Detailed mosquito records and sequence information and can be found on BOLD within the Working Group 1.4 Initiative Human Pathogens and Zoonoses, in the project entitled "Surveillance of Mosquitoes in La Rioja, Spain [LRMQS, MLQSR, MQSLR].” The Digital Object Identifier (DOI) for the BOLD project is: dx.doi.org/10.5883/DS-MQSVLR. Generated sequences were also deposited in GenBank database under accession numbers MK402666 - MK402927 for COI and MK412721 - MK412767 for ITS2. Flavivirus sequence identified was also deposited in GenBank database under under accession number MK501751.

\section{AUTHOR CONTRIBUTIONS}

IR-A and JO designed the study. IR-A conducted the surveys and the morphological and molecular identification. IR-A and LH-T performed the molecular analysis. IR-A and PS conducted the screening for flavivirus. IR-A, BM, AP, and JO outlined the structure of the manuscript. IR-A compiled the main information and wrote the first draft of the manuscript. All authors reviewed and approved the final manuscript.

\section{FUNDING}

This work was partly supported by the European Regional Development Fund (ERDF). LH-T would like thank the EU Framework Horizon 2020 Innovation Grant, European Virus Archive (EVAg, grant no. 653316) and the UK Department for Environment and Rural Affairs (DEFRA), Scottish Government and Welsh Government (grants nos. SV3045, SE4113) for contributions to funding this study.

\section{ACKNOWLEDGMENTS}

The authors would like to thank to Jorge García (URBE Ingeniería) for the elaboration of Figure 1. Thanks are given 
to Dr. Ignacio de Blas and Laura Blanco for their help with Table 2 and Dr. Ana Vázquez for her advices in the screening for flaviviruses. Thanks are also given to Nadya Nikolova for her help in editing COI and ITS2 sequences and efforts in uploading all traces files and sequences on BOLD.

\section{REFERENCES}

1. Beerntsen BT, James AA, Christensen BM. Genetics of mosquito vector competence. Microbiol Mol Biol Rev. (2000) 64:115-37. doi: 10.1128/MMBR.64.1.115-137.2000

2. Tolle MA. Mosquito-borne diseases. Curr Probl Pediatr Adolesc Health Care. (2009) 39:97-140. doi: 10.1016/j.cppeds.2009.01.001

3. Kilpatrick AM. Globalization, land use, and the invasion of West Nile Virus. Science. (2011) 334:323-7. doi: 10.1126/science.1201010

4. Johnson I, Hansen A, Bi, P. The challenges of implementing an integrated One Health surveillance system in Australia. Zoonoses Public Health. (2018) 65:e229-36. doi: 10.1111/zph.12433

5. European Centre for Disease Prevention and Control. Cluster of autochthonous chikungunya cases in France - 23 August 2017. Stockholm: ECDC. (2017). Available online at: https://ecdc.europa.eu/sites/portal/files/documents/RRAChikungunya-France-revised-Aug-2017.pdf

6. Venturi G, Di Luca M, Fortuna C, Remoli ME, Riccardo F, Severini F, et al. Detection of a chikungunya outbreak in Central Italy, August to September 2017. Euro Surveill. (2017) 22. doi: 10.2807/1560-7917.ES.2017.22.39.17-00646

7. Succo T, Leparc-Goffart I, Ferre JB, Roiz D, Broche B, Maquart $\mathrm{M}$, et al. Autochthonous dengue outbreak in Nimes, South of France, July to September 2015. Euro Surveill. (2016) 21. doi: 10.2807/1560-7917.ES.2016.21.21.30240

8. European Centre for Disease Prevention and Control. Local transmission of dengue fever in France and Spain - 2018 - 22 October 2018. Stockholm: ECDC. (2018) Available online at: https://ecdc.europa.eu/en/publications-data/ rapid-risk-assessment-local-transmission-dengue-fever-france-and-spain

9. Fernández-Balbuena S, Fernández González R, Jurado P, Monge Corella S, Palmera-Suárez R, Niveiro MJ, et al. Evaluación rápida de riesgo. Primeros casos de dengue autóctono en España. Secretaría General de Sanidad y Consumo, Dirección General de Salud Pública, Calidad e Innovación, Centro de Coordinación de Alertas y Emergencias Sanitarias, Ministerio de Sanidad, Consumo y Bienestar Social. (2018) Available online at: http://www.mscbs.gob. es/profesionales/saludPublica/ccayes/alertasActual/alertActu.htm

10. Rizzoli A, Jimenez-Clavero MA, Barzon L, Cordioli P, Figuerola J, Koraka P, et al. The challenge of West Nile virus in Europe: knowledge gaps and research priorities. Euro Surveill. (2015) 20:21135. doi: 10.2807/1560-7917.ES2015.20.20.21135

11. Santa-Olalla P, Vazquez-Torres MC, Latorre-Fandos E, Mairal-Claver P, Cortina-Solano P, Puy-Azon A, et al. First autochthonous malaria case due to Plasmodium vivax since eradication, Spain, October 2010. Euro Surveill. (2010) 15:19684. doi: 10.2807/ese.15.41.19684-en

12. Danis K, Lenglet A, Tseroni M, Baka A, Tsiodras S, Bonovas S. Malaria in Greece: historical and current reflections on a reemerging vector borne disease. Travel Med Infect Dis. (2013) 11:8-14. doi: 10.1016/j.tmaid.2013.01.001

13. Barzon L. Ongoing and emerging arbovirus threats in Europe. J Clin Virol. (2018) 107:38-47. doi: 10.1016/j.jcv.2018.08.007

14. Paternoster G, Tomassone L, Tamba M, Chiari M, Lavazza A, Piazzi M, et al. The degree of one health implementation in the West Nile Virus integrated surveillance in Northern Italy, 2016. Front Public Health. (2017) 5:236. doi: 10.3389/fpubh.2017.00236

15. European Centre for Disease Prevention and Control. Guidelines for the surveillance of Native Mosquitoes in Europe. Stockholm: ECDC (2014) Available online at: https://ecdc.europa.eu/sites/portal/files/media/en/ publications/Publications/surveillance- of $\% 20$ native-mosquitoes $\% 20$ guidelines.pdf

\section{SUPPLEMENTARY MATERIAL}

The Supplementary Material for this article can be found online at: https://www.frontiersin.org/articles/10.3389/fvets. 2019.00086/full\#supplementary-material

16. Török E, Tomazatos A, Cadar D, Horváth C, Keresztes L, Jansen S, et al. Pilot longitudinal mosquito surveillance study in the Danube Delta Biosphere Reserve and the first reports of Anopheles algeriensis Theobald, 1903 and Aedes hungaricus Mihalyi, 1955 for Romania. Parasit Vectors. (2016) 9:196. doi: 10.1186/s13071-016-1484-7

17. Ferraguti M, Martínez-de la Puente J, Roiz D, Ruiz S, Soriguer R, Figuerola J. Effects of landscape anthropization on mosquito community composition and abundance. Sci Rep. (2016) 6:29002. doi: 10.1038/srep29002

18. Engler O, Savini G, Papa A, Figuerola J, Groschup MH, Kampen H, et al. European surveillance for West Nile virus in mosquito populations. Int J Environ Res Public Health. (2013) 10:4869-95. doi: 10.3390/ijerph10104869

19. Figuerola J. Por qué no se dan más casos de infección por el virus West Nile en el sur de la Península? Rev Enf Emer. (2018) 17:81-103.

20. Haussig JM, Young JJ, Gossner CM, Mezei E, Bella A, Sirbu A, et al. Early start of the West Nile fever transmission season 2018 in Europe. Euro Surveill. (2018) 23:1800428. doi: 10.2807/1560-7917.ES.2018.23.32.1800428

21. Martínez-de la Puente J, Ferraguti M, Ruiz S, Roiz D, Llorente F, Pérez-Ramírez E, et al. Mosquito community infuences West Nile virus seroprevalence in wild birds: implications for the risk of spillover into human populations. Sci Rep. (2018) 8:2599. doi: 10.1038/s41598-018-20825-Z

22. Sánchez A, Amela C, Santos S, Suárez B, Simón F, Sierra MJ, et al. Informe de situación y evaluación del riesgo para España de Virus del Nilo Occidental. Centro de Coordinación de Alertas y Emergencias Sanitarias (CCAES). Ministerio de Sanidad, Servicios Sociales e Igualdad (2013).

23. Millet JP, Montalvo T, Bueno-Marí R, Romero-Tamarit A, Prats-Uribe A, Fernández L, et al. Imported Zika virus in a European city: How to prevent local transmission? Front Microbiol. (2017) 8:1319. doi: 10.3389/fmicb.2017.01319

24. Palmer JRB, Oltra A, Collantes F, Delgado JA, Lucientes J, Delacour S, et al. Citizen science provides a reliable and scalable tool to track disease-carrying mosquitoes. Nat Comms. (2017) 8:916. doi: 10.1038/s41467-017-00914-9

25. Oteo JA, Ibarra V, Blanco JR, Martínez de Artola V, Márquez FJ, Portillo A, et al. Dermacentor-borne necrosis erythema and lymphadenopathy: clinical and epidemiological features of a new tick-borne disease. Clin Microbiol Infect. (2004) 10:327-31. doi: 10.1111/j.1198-743X.2004.00782.x

26. Ibarra V, Portillo A, Palomar AM, Sanz MM, Metola L, Blanco JR, et al. Septic shock in a patient infected with Rickettsia sibirica mongolitimonae, Spain. Clin Microbiol Infect. (2012) 18:E283-5. doi: 10.1111/j.1469-0691.2012. 03887.x

27. Palomar AM, Portillo A, Mazuelas D, Roncero L, Arizaga J, Crespo A, et al. Molecular analysis of Crimean-Congo hemorrhagic fever virus and Rickettsia in Hyalomma marginatum ticks removed from patients (Spain) and birds (Spain and Morocco), 2009-2015. Ticks Tick Borne Dis. (2016) 7:983-7. doi: 10.1016/j.ttbdis.2016.05.004

28. Gobierno de La Rioja. Plan riojano de acción y Seguimiento Frente a la Emergencia del Virus Zika, Chikungunya y Dengue. (2016). Available online at: https://www.riojasalud.es/f/rs/docs/Plan\%20riojano\%20de\%20acci\%C3 \%B3n\%20y\%20seguimiento\%20frente $\% 20 a \% 20$ la\%20emergencia\%20del \%20virus\%20Zika,\%20Chikungunya\%20y\%20Dengue.pdf

29. García Ruiz JM. El relieve: caracteres generales del relieve. In: Arnáez Vadillo J, García Ruiz JM, editors. Geografía de La Rioja, Vol 1: Geografía física. Logroño: Fundación Caja Rioja (1994). p. 36-8.

30. Ruiz-Arrondo I, Hernández Triana L, Oteo Revuelta JA. Fauna de mosquitos (Diptera, Culicidae) presentes en el humedal de La Grajera (Logroño) y sus implicaciones en Salud Pública. Zubía. (2017) 35:123-40.

31. Medlock J, Balenghien T, Alten B, Versteirt V, Schaffner F. Field Sampling Methods for Mosquitoes, Sandflies, Biting Midges and Ticks. VectorNet project 2014-2018. EFSA supporting publication (2018). 
32. Portillo A, Ruiz-Arrondo I, Oteo JA. Arthropods as vectors of transmissible diseases in Spain. Med Clin. (2018) S0025-7753:30443-3. doi: 10.1016/j.medcli.2018.06.021

33. Alarcón-Elbal PM, Delacour S, Pinal R, Ruiz-Arrondo I, Muñoz A, Bengoa M, et al. Establecimiento y mantenimiento de una colonia autóctona española de Aedes (Stegomyia) albopictus Skuse, 1894, (Diptera, Culicidae) en laboratorio. Parasitol Latinoam. (2010) 69:140-8.

34. Schaffner F, Angel G, Geoffroy B, Hervy JO, Rhaeim A. The mosquitoes of Europe. CD-Rom. Montpellier. IRD Éditions and EID Méditerranée (2001).

35. Becker N, Petric D, Zgomba M, Boase C, Madon M, Dahl C. et al. Mosquitoes and Their Control. 2nd ed. Heidelberg: Springer (2010).

36. Hernandez-Triana LM, Brugman VA, Prosser SWJ, Weland C, Nikolova $\mathrm{N}$, Thorne $\mathrm{L}$, et al. Molecular approaches for blood meal analysis and species identification of mosquitoes (Insecta: Diptera: Culicidae) in rural locations in southern England, United Kingdom. Zootaxa. (2017) 4250:06776. doi: 10.11646/zootaxa.4250.1.5

37. Ruiz-Arrondo I, Hernández-Triana LM, Ignjatović-Ćupina A, Nikolova N, Garza-Hernández JA, Rodríguez-Pérez MA, et al. DNA barcoding of blackflies (Diptera: Simuliidae) as a tool for species identification and detection of hidden diversity in the Eastern regions of Spain. Parasit Vectors. (2018) 11:463. doi: 10.1186/s13071-018-3046-7

38. Sánchez-Seco MP, Rosario D, Domingo C, Hernandez L, Valdes K, Guzmán MG, et al. Generic RT-nested-PCR for detection of flaviviruses using degenerated primers and internal control followed by sequencing for specific identification. J Virol Methods. (2005) 126:101-9. doi: 10.1016/j.jviromet.2005.01.025

39. Lundström JO. Vector competence of western European mosquitoes for arboviruses: a review of field and experimental studies. Bull Soc Vector Ecol. (1994) 19:23-36.

40. Fontenille D, Traore-Lamizana M, Diallo M, Thonnon J, Digoutte JP, Zeller HG. New Vectors of Rift Valley Fever in West Africa. Emerg Infect Dis. (1998) 4:289-93. doi: 10.3201/eid0402.980218

41. Medlock MJ, Snow KR, Leach S. Potential transmission of West Nile virus in the British Isles: an ecological review of candidate mosquito bridge vectors. Med Vet Entomol. (2005) 19:2-21. doi: 10.1111/j.0269-283X.2005.00547.x

42. Chapman GE, Archer D, Torr S, Solomon T, Baylis M. Potential vectors of equine arboviruses in the UK. Vet Rec. (2017) 180:19. doi: 10.1136/vr.103825

43. Alarcón-Elbal PM, Delacour-Estrella S, Ruiz-Arrondo I, Pinal R, Muñoz A, Oropeza V, et al. Los culícidos (Diptera Culicidae) del valle medio del Ebro I: La Rioja (Norte de España). Bol SEA. (2012) 50:359-65.

44. Bueno Marí R. Estudio faunístico y eco-epidemiológico de los mosquitos (Diptera, Culicidae) de La Rioja. Zubía. (2012) 30:141-61.

45. Melero-Alcibar R, Lucientes J, Molina R, Roiz D. Revisión de Uranotaenia (pseudoficlbia) unguiculata Edwards, 1913 en la Península Ibérica (Diptera: Culicidae). Bol SEA. (2005) 36:347-8.

46. Delacour Estrella S, Bravo Minguet D, Alarcón Elbal PM, Bengoa M, Casanova A, Melero Alcíbar R, et al. Nuevas aportaciones al conocimiento de la culicidofauna de Navarra. In: Book of Abstracts XXVIII Jornadas de la Asociación Española de Entomología. Ponferrada: University of León (2011). p. 95

47. Aranda C, Sánchez-Seco MP, Cáceres F, Escosa R, Gálvez JC, Masià M, et al. Detection and monitoring of mosquito flaviviruses in Spain between 2001 and 2005. Vector Borne Zoonotic Dis. (2009) 9:171-8. doi: 10.1089/vbz.2008.0073

48. Vázquez A, Ruiz S, Herrero L, Moreno J, Molero F, Magallanes A, et al. West Nile and Usutu viruses in mosquitoes in Spain, 2008-2009. Am J Trop Med Hyg. (2011) 85:178-81. doi: 10.4269/ajtmh.2011.11-0042

49. Alba A, Allepuz A, Napp S, Soler M, Selga I, Aranda C, et al. Ecological surveillance for West Nile in Catalonia (Spain), learning from a fiveyear period of follow-up. Zoonoses Public Health. (2014) 61:181-91. doi: 10.1111/zph.12048

50. Gobierno de La Rioja. Informe de Resultados de caso de Sospecha de Malaria Autóctona en Viana (Navarra). Dirección General de Salud Pública y Consumo, Gobierno de La Rioja. (2014).

51. Krüger A, Rech A, Su XZ, Tannich E. Two cases of autochthonous Plasmodium falciparum malaria in Germany with evidence for local transmission by indigenous Anopheles plumbeus. Trop Med Int Health. (2001) 6:983-5. doi: 10.1046/j.1365-3156.2001.00816.x
52. Shute PG, Maryon M. Malaria in England past, present and future. J R Soc Promot Health. (1974) 94:23-9. doi: 10.1177/146642407409400111

53. Daskova NG, Rasnicyn SP. Review of data on susceptibility of mosquitoes in the USSR to imported strains of malaria parasites. Bull World Health Organ. (1982) 6D:893-7.

54. Sokolova MI, Snow KR. Malaria vectors in European Russia. Eur Mosq Bull. (2002) 12:1-6.

55. Martínez-de la Puente J, Ferraguti M, Ruiz S, Montalvo, Casimiro T, Soriguer $\mathrm{R}$, et al. Tracing Pathogen Transmission by Mosquitoes Under a Global Change Perspective: On the Role of the Identification of Mosquito Bloodmeals. Chichester: eLS; John Wiley \& Sons Ltd (2018).

56. Kampen H, Sternberg A, Proft J, Bastian S, Schaffner F, Maier WA, et al. Polymerase chain reaction-based differentiation of the mosquito sibling species Anopheles claviger s.s. and Anopheles petragnani (Diptera: Culicidae). Am J Trop Med Hyg. (2003) 69:195-9.

57. Versteirt V, Nagy ZT, Roelants P, Denis L, Breman FC, Damiens D, et al Identification of Belgian mosquito species (Diptera: Culicidae) by DNA barcoding. Mol Ecol Resour. (2015) 15:449-457. doi: 10.1111/1755-0998.12318

58. Gunay F, Alten, B, Simsek F, Aldemir A, Linton YM. Barcoding Turkish Culex mosquitoes to facilitate arbovirus vector incrimination studies reveal hidden diversity and new potential vectors. Acta Trop. (2015) 143:112-20. doi: 10.1016/j.actatropica.2014.10.013

59. Calzolari M, Bonilauri P, Bellini R, Caimi M, Defilippo F, Maioli $\mathrm{G}$, et al. Arboviral survey of mosquitoes in two northern Italian regions in 2007 and 2008. Vector Borne Zoonotic Dis. (2010) 10:875-84. doi: $10.1089 / \mathrm{vbz} .2009 .0176$

60. Calzolari M, Zé-Zé L, RůŽek D, Vázquez A, Jeffries C, Defilippo F, et al. Detection of mosquito-only flaviviruses in Europe. J Gen Virol. (2012) 93:1215-25. doi: 10.1099/vir.0.040485-0

61. Sánchez-Seco MP, Vázquez A, Collao X, Hernández L, Aranda C, Ruiz $\mathrm{S}$, et al. Surveillance of arboviruses in Spanish wetlands: detection of new flavi- and phleboviruses. Vector Borne Zoonotic Dis. (2010) 10:203-6. doi: $10.1089 /$ vbz.2008.0188

62. Vázquez A, Sánchez-Seco MP, Palacios G, Molero F, Reyes N, Ruiz S, et al. Novel flaviviruses detected in different species of mosquitoes in Spain. Vector Borne Zoonotic Dis. (2012) 12:223-9. doi: 10.1089/vbz.2011.0687

63. Bellini R, Calzolari M, Mattivi A, Tamba M, Angelini P, Bonilauri P, et al. The experience of West Nile virus integrated surveillance system in the Emilia-Romagna region: five years of implementation, Italy, 2009 to 2013. Euro Surveill. (2014) 19:20953. doi: 10.2807/1560-7917.ES2014.19. 44.20953

64. Paternoster G, Babo Martins S, Mattivi A, Cagarelli R, Angelini P, Bellini $\mathrm{R}$, et al. Economics of One Health: Costs and benefits of integrated West Nile virus surveillance in Emilia-Romagna. PLoS ONE. (2017) 12:e0188156. doi: 10.1371/journal.pone.0188156

65. Healy JM, Reisen WK, Kramer VL, Fischer M, Lindsey NP, Nasci RS, et al. Comparison of the efficiency and cost of west nile virus surveillance in California. Vector Borne Zoonotic Dis. (2012) 15:147-55. doi: 10.1089/vbz.2014.1689

66. McMahon BJ, Morand S, Gray JS. Ecosystem change and zoonoses in the Anthropocene. Zoonoses Public Health. (2018) 65:755-65. doi: 10.1111/zph.12489

67. Petrović T, Šekler M, Petrić D, Lazić S, Debeljak Z, Vidanović D, et al. Methodology and results of integrated WNV surveillance programmes in Serbia. PLoS ONE. (2018) 13:e0195439. doi: 10.1371/journal.pone.0195439

Conflict of Interest Statement: The authors declare that the research was conducted in the absence of any commercial or financial relationships that could be construed as a potential conflict of interest.

Copyright (C) 2019 Ruiz-Arrondo, McMahon, Hernández-Triana, Santibañez, Portillo and Oteo. This is an open-access article distributed under the terms of the Creative Commons Attribution License (CC BY). The use, distribution or reproduction in other forums is permitted, provided the original author $(s)$ and the copyright owner(s) are credited and that the original publication in this journal is cited, in accordance with accepted academic practice. No use, distribution or reproduction is permitted which does not comply with these terms. 